\title{
Process Optimization of Methylphenidate Hydrochloride Extended Release Pellets by QbD
}

\author{
Bala Vishnu Priya Mukkala ${ }^{1 *}$, Murthy TEGK², Prameela Rani $A^{3}$ \\ ${ }^{1}$ Formulation Research and Development, RA Chem Pharma Ltd, Hyderabad, Telangana, INDIA. \\ ${ }^{2}$ Department of pharmaceutics, Bapatla College of Pharmacy, Guntur, Andhra Pradesh, INDIA. \\ ${ }^{3}$ Department of pharmaceutics, Acharya Nagajuna University, Guntur, Andhra Pradesh, INDIA.
}

\begin{abstract}
Objective: The aim of the present research work was to optimize the process of Methylphenidate Hydrochloride ( $\mathrm{HCl}$ ) Extended releasse (ER) pellets based on Quality by Design $(\mathrm{QbD})$ principles. Materials and methods: Wurster (Bottom spray fluid bed coating) process was employed to develop ER pellets of Methylphenidate $\mathrm{HCl}$. Impact of various process variables on drug layering process was assessed by using statistical interpretation such as ANOVA. A face centered central composite design (CCD) was employed to study the effect of independent variables (product temperature, atomization air pressure, fluidization air volume, and spray rate) on dependent variables (Fines, agglomerates, coating efficiency and assay). Fabricated pellets were characterized for various physicochemical parameters and stability studies. Results: Optimization was done by fitting experimental results to the software program (Design expert). The design space for process parameters and its influence on \%fines, \% agglomerates, coating efficiency and assay was developed. From the obtained results, $40^{\circ} \mathrm{C} \pm 2{ }^{\circ} \mathrm{C}$ as product temperature, $0.8-1.0 \mathrm{~kg} / \mathrm{cm}^{2}$ as atomization air pressure, 45-60 CFM as fluidization air volume and 2-6 $\mathrm{g} / \mathrm{min}$ as spray rate were selected as the operating ranges for robust coating process, desired yield and quality of the product. The drug release from the optimized formulation followed first order kinetics and fickian diffusion process. There is no significant change observed during stability. Conclusion: It was concluded that the face centered central composite design facilitated the process optimization of Methylphenidate $\mathrm{HCI}$ ER pellets. The Methylphenidate $\mathrm{HCl}$ ER pellets were successfully developed by employing bottom spray fluid bed coating (Wurster) technique.
\end{abstract}

Key words: Methylphenidate $\mathrm{HCl}$, Pellets, Central composite design, Process variables.

\section{INTRODUCTION}

Multiple-dose units have many kinetic and therapeutic advantages over single-dose sustained-release units, such as improved bioavailability, easy administration, reproducible gastric residence time, low risk of dose dumping, low intra and inter subject variability, flexibility of blending of different release profiles and divided into various dose strengths without formulation changes. The most commonly used pelletization techniques are suspension/solution layering, extrusion spheronization and powder layering. However, suspension/solution layering (Wurster) technique is most preferable in the pharmaceutical industry owing to its advantages like continuous process, less manual interruption and batch to batch reproducibility. ${ }^{1,2,3}$

The process variables involved in the Wurster process are batch size, air distribution plate, column height, spray nozzle diameter, filter bags, nature of the coating solution/suspension, inlet and product temperature, air volume, dew point, spray rate, atomization air pressure, drying/ curing time etc. Process parameters can be varied in a specific range without a critical effect on the fluid bed process or on the pellet quality. In contrast, a variation of a critical parameter would
Submission Date: 24-08-2017; Revision Date: 25-09-2017; Accepted Date: 18-10-2017

DOI: 10.5530/ijper.51.4s.82 Correspondence:

Dr. Bala Vishnu Priya Mukkala,

Formulation research and development, RA Chem Pharma Ltd, Hyderabad, Telangana INDIA. Phone no: 08643224144 E-mail: vishnupriya.mukkala@gmail.com

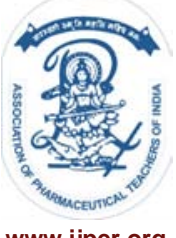

www.ijper.org 
affect the fluid bed process or the pellet quality in a significant manner. ${ }^{4}$

Quality by design (QbD) is a holistic and proactive approach to support the pharmaceutical development in a more scientific, risk based manner, by restricting the flexibility in the manufacturing process to ensure predetermined product specifications. It helps to assess the critical material attributes (CMAs) and critical process parameters (CPPs) that impacting the predefined critical quality attributes (CQAs). ${ }^{5}$

Response surface methodology (RSM) is one of the popular methods in the development and optimization of drug delivery systems. Central composite design (CCD), three level factorial design, Box Behnken design and D-optimal design are the different types of RSM designs available for statistical optimization of the formulations. Face centred central composite design provide relatively high quality predictions over the entire design space and do not require using points outside the original factor range. ${ }^{6}$

Batch size should be kept within the recommended occupancy to obtain batch to batch uniformity. The air distribution plate was selected based on particle size and density of the material used. Appropriate air distribution plate has to be selected to get consistent fluidization at minimum attrition. The height of the column changed on the basis of particle properties such as size, shape and density. Appropriate adjustment of the partition gap ensures proper substrate circulation through the spray zone and drying zone. The droplet size would be controlled by the nozzle diameter used. Hence, it is necessary to select the proper nozzle diameter to get more consistent and uniform spray.

Filter bag is used to prevent loss of material and to allow the air to pass through. A filter bag is selected based on the particle size of the core. Coating solution or suspension should have enough solid content to easy spraying. If the viscosity of coating liquid is more, it will affect the droplet size and leads to change in the pellet surface. Dew point indicates the amount of moisture in the air. The change in dew point of air changes the evaporating efficiency of the air. To eliminate static charge and process variability, required absolute humidity should be maintained. Drying process is a removal of water or volatile solvent from solution or suspension. Drying/ curing time and temperature would be selected based on solvent used and material to be coated.

Control of the inlet air temperature is important parameter as it affects the quality of coats formed. High temperature leads to spray drying and low temperature leads to agglomeration. Fluidization air volume is responsible for circulation and drying of substances during coating.
Insufficient air flow may not provide sufficient drying air and consequently results in agglomeration. However, excessively high air flow rates can increase the attrition, leads to friable cores or stress cracks on coats and augment the spray drying effect.

Spray rate depends on the size of the core particles as well as the solution properties. Spray rate has to be adjusted according to the drying efficiency and tackiness of the solution. High spray rates increase the propensity for agglomeration and results in non-uniform cores. Low spray rates also enable smaller spray droplets to be formed which would increase the coat uniformity, reduce agglomeration.

Atomization air pressure controls the droplet size and thereby influences the spray pattern. High atomization air pressure result in smaller spray droplets and are required to prevent agglomeration , however high atomization air pressures also increases the attrition of cores and can produce more fines. On the other hand, low atomizing air pressure leads to formation of coarser droplets, which dry slowly and result in agglomeration. ${ }^{4,7}$

Methylphenidate $\mathrm{HCl}$ is used to treat attention deficit hyperactivity disorder. The short biological half-life and multiple dosing regimen of Methylphenidate $\mathrm{HCl}$ are appropriate properties to develop extended release formulation, which provides a longer duration of effect after a single dose. Research done on osmotic tablets of Methylphenidate $\mathrm{HCl}$ and Controlled release pellets by conventional coating pan. ${ }^{8,9}$ Hence, the present investigation aimed to fabricate a Methylphenidate $\mathrm{HCl}$ extended release (ER) pellets employing Wurster process. There are no reported studies available as present investigation. Impact of the formulation variables were statistically interpreted and significant formulation variables were optimized employing factorial design in our earlier investigation. ${ }^{10}$ Preliminary studies were carried out to freeze the process parameters which do not have any impact on product quality, such as batch size, air distribution plate, column height, spray nozzle diameter, filter bags, dew point and drying time. However, Product temperature, atomization air pressure fluidization air volume and spray rate are found as critical process parameters.

\section{MATERIALS AND METHODS MATERIALS}

Methylphenidate $\mathrm{HCl}$ was obtained from RA CHEM Pharma Ltd., Hyderabad as gift sample, Sugar spheres (Arun pharma), Hypromellose (Dow chemical's), Povidone (BASF), Talc (Luzenac), Eudragit RSPO (Evonik), Eudragit L 30 D55 (Evonik), Triethyl citrate 
(Merck), Isopropyl alcohol (Avantor), Purified water and empty hard gelatin capsule shells size 1 (ACG) were used as received.

\section{METHODS}

\section{Preparation of Methylphenidate $\mathrm{HCl}$ Extended Release (ER) Pellets by Wurster process:}

Methylphenidate $\mathrm{HCl}$ ER Pellets were prepared by employing bottom - spray fluid bed (Wuster) coating process (Glatt GPCG 1.1). The dosage form was designed to obtain the biphasic release profile from single population of pellets comprisfing immediate release and extended release portions. Dose was distributed among the two portions equally, i.e. $50 \%$ as immediate release portion and second part as extended release portion.

Drug loaded pellets were prepared by spraying the aqueous drug dispersion over non pariel seeds (Sugar spheres (20\#- 25\# ASTM)) employing wurster process (Bottom spray fluid bed coating technology). Further, Hypromellose dispersion was coated on to the drug loaded pellets. Hydro alcoholic (IPA : Water 80:20) Eudragit RSPO dispersion was coated over the seal coated pellets using Wurster process. Further, the Eudragit L 30 D 55 dispersion was coated on to the ER coated pellets. Finally, immediate release portion (50\%) of drug dispersion was coated over the enteric coated pellets. IR drug loaded pellets were sifted through \#16\#20 ASTM mesh to separate the fines and agglomerates and collect the desired portion. The composition of the optimized formula described in Table 1.

\section{Experimental Design}

In preliminary trials, the process parameters were evaluated for their significance on pellet quality. Finally, Product temperature, atomization air pressure, fluidization air volume and spray rate are found as critical process parameters.

The Face centred central composite design was used to evaluate the effect of critical process parameters on responses/dependent variables ( $\%$ Fines $\left(\mathrm{Y}_{1}\right), \%$ Agglomerates $\left(\mathrm{Y}_{2}\right)$, Coating efficiency $\left(\mathrm{Y}_{3}\right)$ and Assay $\left(\mathrm{Y}_{4}\right)$ ) of Methylphenidate $\mathrm{HCl}$ ER pellets drug layering process. A four factor, three level design is used for exploring quadratic response surfaces and constructing second order polynomial models with Design Expert (Stat-Ease).

Analysis of variance (ANOVA) is inevitably linked to experimental design, which was used to analyse significance of the model and each selected response. It was also generate polynomial equations. The response $\left(\mathrm{Y}_{1}\right)$ in each trial was estimated by carrying out a multiple factorial regression analysis using the generalized quadratic model:

$\mathrm{Y}_{1}=\mathrm{b}_{0}+\mathrm{b}_{1} \mathrm{X}_{1}+\mathrm{b}_{2} \mathrm{X}_{2}+\mathrm{b}_{3} \mathrm{X}_{3}+\mathrm{b}_{4} \mathrm{X}_{4}+\mathrm{b}_{5} \mathrm{X}_{1} \mathrm{X}_{2}+$ $\mathrm{b}_{6} \mathrm{X}_{2} \mathrm{X}_{3}+\mathrm{b}_{7} \mathrm{X}_{3} \mathrm{X}_{4}+\mathrm{b}_{8} \mathrm{X}_{4} \mathrm{X}_{1}+\mathrm{b}_{9} \mathrm{X}_{1}^{2}+\mathrm{b}_{10} \mathrm{X}_{2}^{2}+\mathrm{b}_{11} \mathrm{X}_{3}^{2}+$ $\mathrm{b}_{12} \mathrm{X}_{4}^{2}$

Where $Y_{1}$ is the measured response associated with each factor level combination; $b_{0}$ is an intercept; $b_{1}$ and $b_{2}$ are regression coefficients computed from the observed experimental values of $\mathrm{Y}_{1}$; and $\mathrm{X}_{1}, \mathrm{X}_{2}, \mathrm{X}_{3}$ and $\mathrm{X}_{4}$ are the coded levels of independent variables, $\mathrm{X}_{1} \mathrm{X}_{2}, \mathrm{X}_{2} \mathrm{X}_{3}, \mathrm{X}_{3}$ $\mathrm{X}_{4}$ and $\mathrm{X}_{4} \mathrm{X}_{1}$ are the interaction terms and the polynomial terms $\left(\mathrm{X}_{1}^{2}, \mathrm{X}_{2}^{2}, \mathrm{X}_{3}^{2}\right.$ and $\left.\mathrm{X}_{4}^{2}\right)$ are used to assess the non-linearity.

After fitting the response data in experimental design as in Table 2, the experimental results were analysed by ANOVA. It demonstrated the various statistical parameters such as $b$ coefficients, $F$ values, $p$ values of model terms and Correlation coefficient $\left(\mathrm{R}^{2}\right)$ values. The suitability of model was authenticated by the predicted and adjusted $\mathrm{R}^{2}$ values ${ }^{11}$.

\section{Optimization of Drug layering process}

The independent variables in drug layering process were product temperature, atomization air pressure, and fluidization air volume and spray rate. These process variables were studied at three levels $(-1,0,+1)$, the +1 and -1 levels were selected based on preliminary experiments and product characteristics. Product temperature was selected based on the solvent used for coating solution preparation, atomization air pressure and fluidization air volume were adjusted based on the core size, and spray rate was selected on the process efficiency. Percentage of fines $\left(\mathrm{Y}_{1}\right)$, percentage of agglomerates $\left(\mathrm{Y}_{2}\right)$, coating efficiency $\left(\mathrm{Y}_{3}\right)$ and assay $\left(\mathrm{Y}_{4}\right)$ were selected as responses. The impact of each selected process parameter on responses were studied and optimized individually.

\section{Evaluation of Methylphenidate HCI ER Pellets}

$\%$ fines, $\%$ agglomerates and coating efficiency were determined using following formulae

$\%$ Fines $=($ Weight of passess $(\mathrm{g}) /$ Total weight of pellets $(\mathrm{g})) \times 100$

$\%$ Agglomerates $=($ Weight of retains $(\mathrm{g}) /$ Total weight of pellets $(\mathrm{g})) \times 100$

Coating efficiency $(\% \mathrm{w} / \mathrm{w})=($ Actual percent weight gain/ Theoretical percent weight gain $) \times 100$

\section{Micromeritic properties ${ }^{12}$}

Bulk density (BD), tapped density (TD) and Hausner ratio (HR) of pellets were determined. $\mathrm{BD}$ and $\mathrm{TD}$ were 


\begin{tabular}{|c|c|c|}
\hline S.no. & Ingredient & mg/capsule \\
\hline $\mathbf{I}$ & \multicolumn{2}{|l|}{ Core } \\
\hline 1 & Sugar Spheres (\#20-\#25) & 150.25 \\
\hline II & \multicolumn{2}{|l|}{ Drug Loading } \\
\hline 2 & Methylphenidate $\mathrm{HCl}$ & 20.00 \\
\hline 3 & Povidone & 3.64 \\
\hline 4 & Hypromellose (Pharma coat 606) & 7.27 \\
\hline 5 & Polyethylene glycol 6000 & 1.09 \\
\hline 6 & Talc & 1.82 \\
\hline 7 & Purified water & Q.S \\
\hline III & \multicolumn{2}{|l|}{ Seal Coating } \\
\hline 8 & Hypromellose (Pharma coat 606) & 18.18 \\
\hline 9 & Polyethylene glycol 6000 & 1.82 \\
\hline 10 & Talc & 1.82 \\
\hline 11 & Purified Water & Q.S \\
\hline IV & \multicolumn{2}{|l|}{ Extended Release Coating } \\
\hline 12 & Ammonio Methacrylate Copolymer Type B (Eudragit RSPO) & 12.73 \\
\hline 13 & Triethyl citrate & 2.55 \\
\hline 14 & Talc & 3.20 \\
\hline 15 & Isopropyl alcohol & Q.S \\
\hline 16 & Purified Water & Q.S \\
\hline V & \multicolumn{2}{|l|}{ Enteric Coating } \\
\hline 17 & Methacrylic Acid- Ethyl Acrylate Copolymer (1:1) Dispersion 30\% (Eudragit L 30 D-55) & 72.73 \\
\hline 18 & Triethylcitrate & 14.55 \\
\hline 19 & Talc & 18.18 \\
\hline 20 & Purified Water & Q.S \\
\hline VI & \multicolumn{2}{|l|}{ Drug Loading } \\
\hline 21 & Methylphenidate $\mathrm{HCl}$ & 20.00 \\
\hline 22 & Povidone & 3.64 \\
\hline 23 & Hypromellose (Pharma coat 606) & 7.27 \\
\hline 24 & Polyethylene glycol 6000 & 1.09 \\
\hline 25 & Talc & 1.82 \\
\hline \multirow[t]{2}{*}{26} & Purified Water & Q.S. \\
\hline & TOTAL & 363.63 \\
\hline
\end{tabular}

\begin{tabular}{|c|c|c|c|}
\hline \multirow{2}{*}{ Factor } & \multicolumn{3}{|c|}{ Levels used, actual (coded) } \\
\hline & Low(-1) & Medium(0) & High(+1) \\
\hline Product temperature $\left({ }^{\circ} \mathrm{C}\right)(\mathrm{A})$ & 30 & 40 & 50 \\
\hline Atomization air pressure $\left(\mathrm{kg} / \mathrm{cm}^{2}\right)(B)$ & 0.8 & 1.0 & 1.2 \\
\hline Fluidization air volume (CFM) (C) & 30 & 50 & 70 \\
\hline Spray rate (g/min) (D) & 1 & 4 & 7 \\
\hline Dependant variables & \multicolumn{3}{|c|}{ Constraints } \\
\hline$Y_{1}=\%$ Fines & \multicolumn{3}{|c|}{ Not more than $2 \% \mathrm{w} / \mathrm{w}$} \\
\hline$Y_{2}=\%$ Agglomerates & \multicolumn{3}{|c|}{ Not more than $2 \% \mathrm{w} / \mathrm{w}$} \\
\hline$Y_{3}=$ Coating efficiency $(\% \mathrm{w} / \mathrm{w})$ & \multicolumn{3}{|c|}{ Not less than $95 \%$ w/w } \\
\hline $\mathrm{Y}_{4}=$ Assay $(\% \mathrm{w} / \mathrm{w})$ & \multicolumn{3}{|c|}{$95 \% w / w$ to $105 \% w / w$} \\
\hline
\end{tabular}


determined by USP method I using a Tapped density tester.

Bulk density $=$ Weight of the sample $(\mathrm{g}) /$ Untapped volume (ml)

Tapped density $=$ Weight of the sample $(\mathrm{g}) /$ Tapped volume (ml)

Hausner ratio were calculated using following formulae Hausner ratio $=\mathrm{TD} / \mathrm{BD}$

Where, TD and $\mathrm{BD}$ are tapped and bulk densities.

\section{Assay $^{13}$}

Methylphenidate $\mathrm{HCl}$ ER Pellets equivalent to $20 \mathrm{mg}$ of Methylphenidate $\mathrm{HCl}$ were transferred into $100 \mathrm{~mL}$ volumetric flask. Diluent ((Methanol: Acetonitrile: $\mathrm{pH}$ 4.0 Sodium acetate buffer at a ratio of 4:3:3) was added to the flask and allowed for sonication about $15 \mathrm{Min}$. Made up the volume with diluent. Transferred $10 \mathrm{~mL}$ of this solution to $20 \mathrm{~mL}$ volumetric flask and made the volume up to the mark. The solution was filtered through $0.45 \mu$ nylon membrane filter. The following chromatographic conditions (isocratic) were employed for analysis.

Column : Kromosil 60, CN $250 \mathrm{~mm} \times 4.6$ $\mathrm{mm}, 5 \mu \mathrm{m}$ or its equivalent

Injection volume : $50 \mu \mathrm{L}$

Flow rate : $1.5 \mathrm{~mL} / \mathrm{min}$

Detector : UV, 210nm

Run time : 10 Min

\section{In vitro drug release studies ${ }^{14}$}

The Methylphenidate $\mathrm{HCl}$ ER pellets equivalent to $40 \mathrm{mg}$ Methylphenidate $\mathrm{HCl}$ were accurately filled into size 1 hard gelatin capsules and evaluated for in vitro drug release studies, which were performed using USP Type I dissolution test apparatus. The volume of the dissolution medium was $500 \mathrm{ml}$ with a stirring speed of $75 \mathrm{rpm}$, and the temperature was maintained at $37^{\circ} \mathrm{C} \pm 0.5^{\circ} \mathrm{C}$. These conditions were kept constant for all dissolution studies. The study was carried out in $0.01 \mathrm{~N} \mathrm{HCl}$ for $2 \mathrm{~h}$ followed by pH 6.8 Phosphate buffer at 1, 2, 3, 4, 6 and 8 h. $10 \mathrm{ml}$ of sample was withdrawn periodically and replaced with equal volume of fresh dissolution medium. The collected samples were filtered through $0.45 \mu$ nylon membrane filter and analyzed to assess the \% drug dissolved by employing same chromatographic conditions as that of assay.

\section{Drug release kinetics ${ }^{15}$}

The drug release kinetics and mechanism from the formulations were studied by fitting the data obtained from the in vitro release study into several mathematical equations.

\section{Stability studies ${ }^{16}$}

The optimized formulation of Methylphenidate $\mathrm{HCl}$ ER pellets were filled into hard gelatin capsules and subjected for stability studies according to international conference of harmonization (ICH) guidelines at an accelerated $\left(40^{\circ} \mathrm{C} / 75 \% \mathrm{RH}\right)$ and long term $\left(25^{\circ} \mathrm{C} / 60 \% \mathrm{RH}\right)$ stability conditions.

\section{RESULTS AND DISCUSSION}

\section{Preparation of pellets}

Methylphenidate $\mathrm{HCl}$ ER pellets was prepared by employing wurster process. The impact of process variables on pellet quality such as \% Fines, \% Agglomerates, Coating efficiency and Assay in preliminary trials. From the obtained results, batch size (30\% occupancy), air distribution plate (' $\mathrm{C}$ ' Plate), spray nozzle diameter

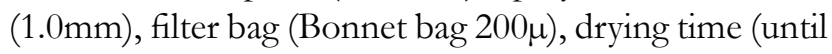
reaches the product temperature) were selected.

Product temperature (A), atomization air pressure (B), fluidization air volume (C) and spray rate (D) were identified as high risk variables, have a potential impact on pellet quality ( $\%$ Fines, $\%$ agglomerates, coating efficiency and assay). Hence these factors were studied by a four factor, three level face centered central composite experimental design, individually.

\section{Data analysis and model validation Fitting of data to the model}

Four factors with three levels face centred central composite experimental design require 19 experiments, the independent variables and responses for all experimental runs are given in Table 3. Models of various responses were obtained using Design Expert (Stat-Ease). The ANOVA results of each response was represented in Table 4 . Values of probability $\mathrm{p}<0.05$ represent significant model terms. The regression equations carry factors along with coefficients (positive/ negative) which quantify response values. A positive sign of coefficient indicates synergistic effects; whereas negative sign represents an antagonistic effect. After elimination of non-significant $(p>0.05)$ coefficients from the obtained results, following correlations for response variables were obtained:

$\mathrm{Y}_{1}=25.64534-0.70964 * \mathrm{~A}-0.23032 * \mathrm{C}+0.00156 * \mathrm{AC}+$ $0.12188 * \mathrm{BC}-1.02083 * \mathrm{BD}-0.00896 * \mathrm{CD}+0.00545 *$ $\mathrm{A}^{2}+0.001113 * \mathrm{C}^{2}$

$\mathrm{Y}_{2}=12.95238-0.10703 * \mathrm{~A}-0.089427 * \mathrm{C}-0.88976 *$ D-0.6500* AB-0.017500* AD-0.23750* BC +0.012917

$* \mathrm{CD}+0.00965 * \mathrm{~A}^{2}+24.12602 * \mathrm{~B}^{2}+0.00279 * \mathrm{C}^{2}+$ $0.17945 * \mathrm{D}^{2}$

$\mathrm{Y}_{3}=18.79475+1.36250 * \mathrm{AB}-76.43293 \mathrm{~B}^{2}-0.37304 \mathrm{D}^{2}$ 


\begin{tabular}{|c|c|c|c|c|c|c|c|}
\hline \multicolumn{4}{|c|}{ Independent Variables } & \multicolumn{4}{|c|}{ Dependent Variables/Responses } \\
\hline $\begin{array}{l}\text { Product } \\
\text { temperature } \\
\left({ }^{\circ} \mathrm{C}\right)(\mathrm{A})\end{array}$ & $\begin{array}{l}\text { Atomization } \\
\text { air pressure } \\
\left(\mathrm{kg} / \mathrm{cm}^{2}\right)(\mathrm{B})\end{array}$ & $\begin{array}{l}\text { Fluidization air } \\
\text { volume (CFM) } \\
\text { (C) }\end{array}$ & $\begin{array}{l}\text { Spray rate } \\
\text { (g/min) (D) }\end{array}$ & $\begin{array}{c}\text { Fines }(\% w / w) \\
\left(Y_{1}\right)\end{array}$ & $\begin{array}{c}\text { Agglomerates } \\
(\% \mathrm{w} / \mathrm{w}) \\
\left(\mathrm{Y}_{2}\right)\end{array}$ & $\begin{array}{l}\text { Coating } \\
\text { efficiency } \\
(\% w / w)\left(Y_{3}\right)\end{array}$ & $\begin{array}{c}\text { Assay }(\% w / w) \\
\left(Y_{4}\right)\end{array}$ \\
\hline 50 & 1.2 & 30 & 1 & 1.5 & 4.5 & 90.1 & 90.7 \\
\hline 50 & 0.8 & 30 & 7 & 2.2 & 4.5 & 87.9 & 88.4 \\
\hline 40 & 1.0 & 70 & 4 & 1.1 & 0.8 & 97.0 & 97.2 \\
\hline 50 & 0.8 & 70 & 7 & 2.1 & 7.1 & 88.8 & 89.0 \\
\hline 30 & 0.8 & 30 & 1 & 0.1 & 2.9 & 88.4 & 88.7 \\
\hline 30 & 0.8 & 70 & 1 & 0.9 & 2.8 & 89.7 & 90.0 \\
\hline 50 & 1.2 & 70 & 1 & 5.5 & 0.2 & 89.0 & 90.4 \\
\hline 40 & 1.0 & 50 & 4 & 0.2 & 0.1 & 98.9 & 99.7 \\
\hline 50 & 1.0 & 50 & 4 & 1.4 & 0.2 & 96.4 & 96.9 \\
\hline 40 & 1.0 & 50 & 7 & 0.7 & 2.5 & 96.4 & 96.9 \\
\hline 30 & 1.2 & 70 & 7 & 1.0 & 7.6 & 87.0 & 87.8 \\
\hline 40 & 1.0 & 50 & 4 & 0.3 & 0.1 & 99.6 & 101.1 \\
\hline 30 & 1.0 & 50 & 4 & 0.4 & 1.8 & 96.2 & 97.4 \\
\hline 40 & 1.0 & 50 & 1 & 0.3 & 0.8 & 92.9 & 94.5 \\
\hline 40 & 0.8 & 50 & 4 & 0.2 & 1.1 & 96.1 & 96.4 \\
\hline 40 & 1.0 & 50 & 4 & 0.4 & 0.3 & 99.1 & 100.0 \\
\hline 40 & 1.0 & 30 & 4 & 0.5 & 1.5 & 94.9 & 95.7 \\
\hline 30 & 1.2 & 30 & 7 & 0.4 & 8.4 & 85.7 & 86.0 \\
\hline 40 & 1.2 & 50 & 4 & 1.0 & 0.9 & 93.8 & 94.5 \\
\hline
\end{tabular}

\begin{tabular}{|c|c|c|c|c|c|c|}
\hline & DF & ss & MS & $\mathbf{F}$ & $\mathbf{P}$ & $\mathbf{R}^{2}$ \\
\hline \multicolumn{7}{|c|}{ Fines (Y1 (\%w/w)) } \\
\hline Model & 14 & 27.51 & 1.96 & 33.15 & 0.0020 & 0.9915 \\
\hline Lack of Fit & 2 & 0.22 & 0.11 & 10.86 & & \\
\hline \multicolumn{7}{|c|}{ Agglomerates (Y2 (\%w/w)) } \\
\hline Model & 14 & 128.87 & 9.21 & 548.11 & $<0.0001$ & 0.9995 \\
\hline Lack of Fit & 2 & 0.041 & 0.020 & 1.52 & & \\
\hline \multicolumn{7}{|c|}{ Coating efficiency (Y3 (\%w/w)) } \\
\hline Model & 14 & 363.77 & 25.98 & 23.62 & 0.0038 & 0.9880 \\
\hline Lack of Fit & 2 & 4.14 & 2.07 & 15.92 & & \\
\hline \multicolumn{7}{|c|}{ Assay (Y4 (\%w/w)) } \\
\hline Model & 14 & 386.26 & 27.59 & 18.43 & 0.0061 & 0.9847 \\
\hline Lack of Fit & 2 & 4.90 & 2.45 & 4.51 & & \\
\hline
\end{tabular}

ANOVA: Analysis of variance; df: Degrees of Freedom; SS: Sum of squares; MS:Mean sum of squares; * $p<0.05$ considered as significant. 
$\mathrm{Y}_{4}=1.67142-84.38008 * \mathrm{~B}^{2}-0.005938 * \mathrm{C}^{2}-0.34724 * \mathrm{D}^{2}$

All the responses observed for various formulations were fitted simultaneously to first order, second order and quadratic models using Design expert. All the responses were found to follow quadratic model. From the obtained ANOVA results Table 4, terms AC, BC, $\mathrm{A}^{2}$ and $\mathrm{C}^{2}$ have positive impact on $\mathrm{Y}_{1}$, whereas $\mathrm{A}, \mathrm{C}, \mathrm{BD}$ and $\mathrm{CD}$ have a negative impact on $\mathrm{Y}_{1}$.Terms $\mathrm{CD}, \mathrm{A}^{2}$, $\mathrm{B}^{2}, \mathrm{C}^{2}$ and $\mathrm{D}^{2}$ shown a positive impact on $\mathrm{Y}_{2}$, whereas $A, C, D, A D$ and $B C$ have a negative impact on $Y_{2}$. AB shown a positive impact on $\mathrm{Y}_{3}$, whereas $\mathrm{B}^{2}$ and $\mathrm{D}^{2}$ have a negative impact on $\mathrm{Y}_{3} . \mathrm{B}^{2}, \mathrm{C}^{2}$ and $\mathrm{D}^{2}$ shown a negative impact on $\mathrm{Y}_{4}$.

\section{Contour and three dimensional response surface plot analysis}

The design expert software (Stat-Ease) generated the contour and three dimensional surface plots are presented in Figure 1, 2, 3, 4, which are very useful to study the interaction effects of the factors on responses. This type of the plot visualizes the effects of two factors on the response at a time. In all the cases, the responses exhibited a nonlinear relationship with factors $Y_{1}, Y_{2}$, $\mathrm{Y}_{3}$ and $\mathrm{Y}_{4}$.

The $\%$ fines were increased with increase in product temperature and fluidization air volume beyond $48^{\circ} \mathrm{C}$ and $60 \mathrm{CFM}$ respectively. The \% agglomerates were increased with decrease in product temperature and fluidization air volume less than $35^{\circ} \mathrm{C}$ and $40 \mathrm{CFM}$ respectively, increase in spray rate beyond $6 \mathrm{~g} / \mathrm{min}$. The coating efficiency was decreased with increase in atomization air pressure, product temperature, fluidization air

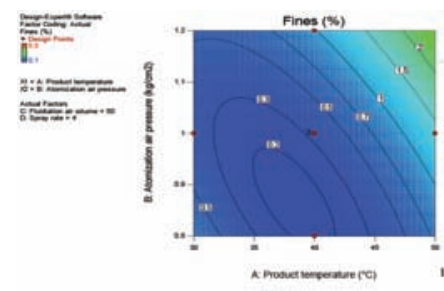

(A)

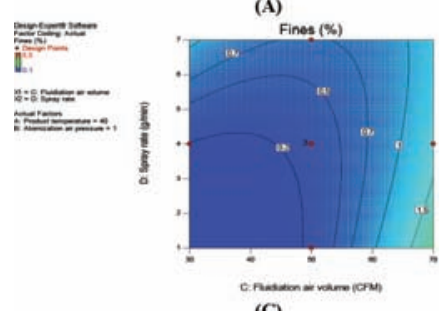

(C)

Figure 1: Contour plots $(A, C)$ and response surface plots $(B, D)$ showing the impact of factors (Product temperature, Atomization air pressure, Fluidization air volume and Spray rate) on percentage of fines.

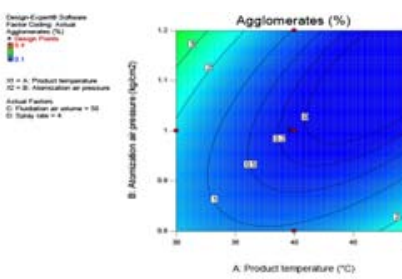

(A)

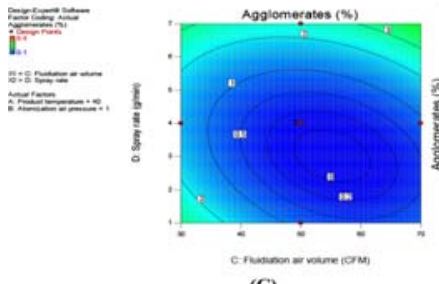

(C)

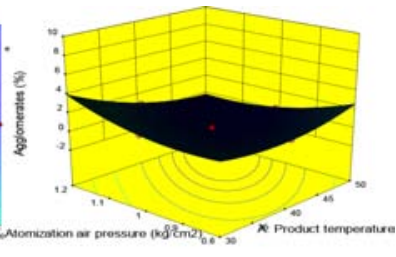

(B)

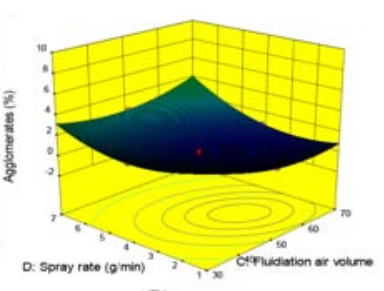

(D)
Figure 2: Contour plots $(\mathrm{A}, \mathrm{C})$ and response surface plots $(B, D)$ showing the impact of factors (Product temperature, Atomization air pressure, Fluidization air volume and Spray rate) on percentage of agglomerates.
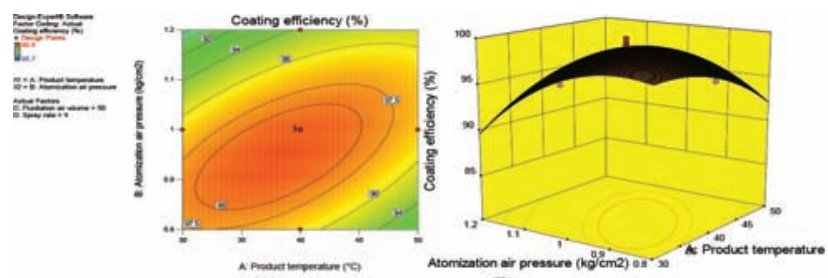

(A)

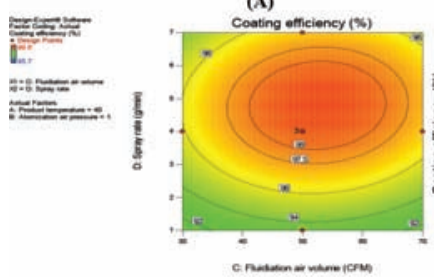

(C)
(B)

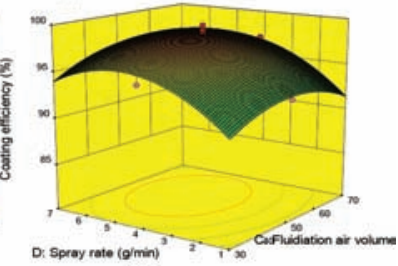

Figure 3: Contour plots $(\mathrm{A}, \mathrm{C})$ and response surface plots $(B, D)$ showing the impact of factors (Product temperature, Atomization air pressure, Fluidization air volume and Spray rate) on coating efficiency.

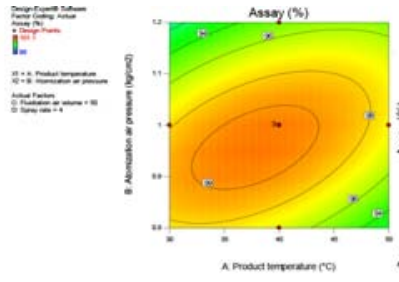

(A)

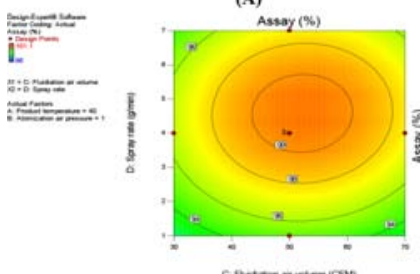

(C)

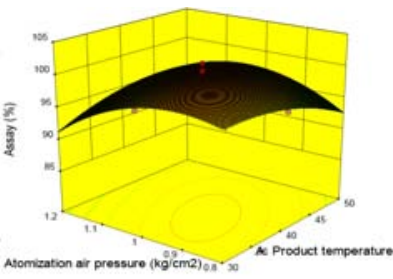

(B)

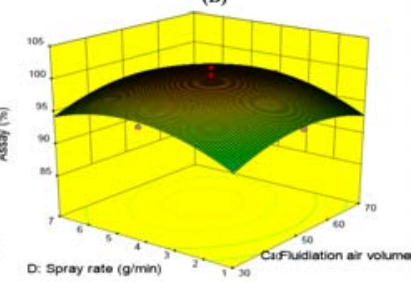

(D)
Figure 4: Contour plots $(A, C)$ and response surface plots $(B, D)$ showing the impact of factors (Product temperature, Atomization air pressure, Fluidization air volume and Spray rate) on assay. 


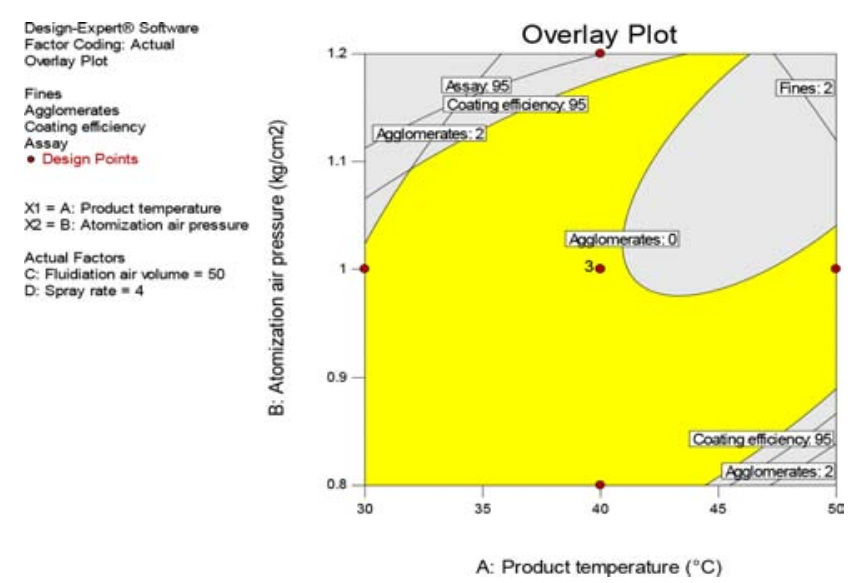

Figure 5: Overlay plot

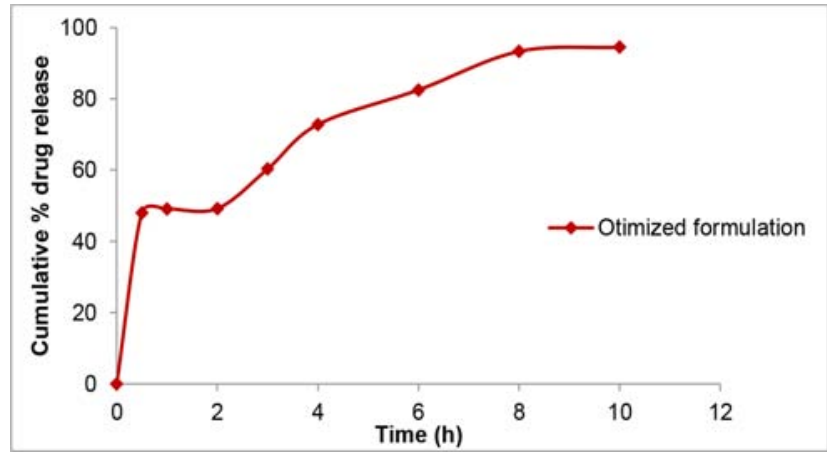

Figure 6: Dissolution profile of the optimized formulation volume greater than $1.1 \mathrm{~kg} / \mathrm{cm}^{2}, 48^{\circ} \mathrm{C}, 60 \mathrm{CFM}$ respectively, spray rate less than $1 \mathrm{~g} / \mathrm{min}$ and fluidization air volume less than 40 CFM. Assay was decreased with increase in product temperature, atomization air pressure beyond $48^{\circ} \mathrm{C}$ and $60 \mathrm{CFM}$ respectively. Assay was decreased with decrease in spray rate and fluidization air volume less than $2 \mathrm{~g} / \mathrm{min}$ and 40 CFM respectively.

The $\%$ fines, $\%$ agglomerates, coating efficiency and assay from all the batches, ranges from $0.2-5.5 \% \mathrm{w} / \mathrm{w}$, $0.1-8.4 \% \mathrm{w} / \mathrm{w}, 85.7-99.6 \% \mathrm{w} / \mathrm{w}$ and $86-101.1$ $\% \mathrm{w} / \mathrm{w}$ respectively.

Among the studied range, the product temperature of $40^{\circ} \mathrm{C} \pm 2^{\circ} \mathrm{C}$ was selected as an optimum, where the high temperature leads to fines generation and poor coating efficiency as well as low temperature results in agglomerates formation due to poor evaporation efficiency. Atomization air pressure of $0.8-1.0 \mathrm{~kg} / \mathrm{cm}^{2}$ was selected as appropriate, owing to the generation of fine mist at high atomization air pressure leads to spray drying and poor coating efficiency. Fluidization air volume of 45 - 60 CFM was selected as suitable air volume to maintain consistent coating and drying cycles. Spray rate of 2-6 $\mathrm{g} / \mathrm{min}$ was selected as an optimum, due to high spray rates results in agglomerates formation and too low spray rates results in poor coating efficiency Figure 5. The results obtained from the formulation executed with optimized formulation and process variables were $\%$ fines $-0.4 \% \mathrm{w} / \mathrm{w}, \%$ agglomerates $-0.3 \% \mathrm{w} / \mathrm{w}$, coating efficiency- $99.1 \% \mathrm{w} / \mathrm{w}$ and assay $-100.2 \% \mathrm{w} / \mathrm{w}$.

Same process parameters were adopted for both extended release (ER) coating and enteric coating process, except product temperature. $36^{\circ} \mathrm{C} \pm 2^{\circ} \mathrm{C}$ and $30^{\circ} \mathrm{C} \pm 2^{\circ} \mathrm{C}$ were selected as product temperature for ER coating and enteric coating processes respectively, as recommended by excipient manufacturer.

\section{Evaluation of pellets}

\section{Micromeretic properties}

The bulk and tapped density of batches ranges from $0.64-0.67 \mathrm{~g} / \mathrm{cc}$ and $0.72-0.80 \mathrm{~g} / \mathrm{cc}$ respectively. The Hausner's ratio values (1.046-1.075) indicated excellent flow properties according to USP limits. Excellent flow properties of the pellets facilitate the fill weight uniformity while capsule filling process.

\section{Assay}

The assay of the all formulations was tested and results were found in the range of $86.0-101.1 \% \mathrm{w} / \mathrm{w}$. Assay of the optimized formulation was observed to be $100.2 \%$.

\section{In vitro drug release studies}

Drug release from the optimized formulation was well within the predetermined specifications Figure 6.

\section{Drug release kinetics}

The dissolution data of optimized formulation fitted into kinetic models, the obtained results concluded that the drug release followed the first order kinetics as $r^{2}$ values were higher for first order model (0.962) than zero order model (0.768). The $\mathrm{n}$ value is less than 0.45 (0.261); hence the mechanism of drug release was fickian diffusion.

\section{Stability studies}

The optimized formulation was subjected for stability studies both at an accelerated $\left(40^{\circ} \mathrm{C} / 75 \% \mathrm{RH}\right)$ and long term $\left(25^{\circ} \mathrm{C} / 60 \% \mathrm{RH}\right)$ stability conditions. Results shown that there was no significant change in description, assay, and in vitro drug release at $40^{\circ} \mathrm{C} \pm 2{ }^{\circ} \mathrm{C}, 75 \% \mathrm{RH}$ and $25^{\circ} \mathrm{C} \pm 2{ }^{\circ} \mathrm{C}, 60 \%$ RH till 6 months Table 5 and 6 . 


\begin{tabular}{|c|c|c|c|c|c|}
\hline $\begin{array}{c}\text { Table 5: Stability results of optimized formulation at Accelerated } \\
\text { 75\%RH) storage conditions. }\end{array}$ \\
\hline \multirow{5}{*}{ Parameter } & \multicolumn{5}{c|}{$\mathbf{C}_{ \pm} \mathbf{2}^{\circ} \mathbf{C}$ and } \\
& Initial & 1 Month & 2 Month & 3 Month & $\mathbf{6}$ Month \\
\cline { 2 - 6 } & White to off-white spherical pellets filled in white opaque capsule \\
\hline Description & 2.54 & 2.25 & 2.17 & 2.19 & 1.99 \\
\hline Moisture content & 100.2 & 99.9 & 99.7 & 99.3 & 99.1 \\
\hline Assay & \multicolumn{5}{|c|}{ Dissolution } \\
\hline \multicolumn{7}{|c|}{} & $49.2 \pm 1.3$ & $49.6 \pm 1.5$ & $49.4 \pm 1.9$ & $49.5 \pm 2.1$ & $49.1 \pm 1.8$ \\
\hline $\mathbf{2}$ & $72.8 \pm 0.9$ & $72.3 \pm 1.1$ & $72.2 \pm 1.6$ & $71.7 \pm 1.8$ & $71.2 \pm 1.5$ \\
\hline $\mathbf{4}$ & $82.5 \pm 0.8$ & $83.4 \pm 0.9$ & $84.1 \pm 0.8$ & $83.9 \pm 1.1$ & $83.6 \pm 1.1$ \\
\hline $\mathbf{6}$ & $93.3 \pm 0.9$ & $94.2 \pm 0.5$ & $93.5 \pm 0.9$ & $93.1 \pm 0.7$ & $92.1 \pm 0.6$ \\
\hline
\end{tabular}

\begin{tabular}{|c|c|c|c|}
\hline \multicolumn{4}{|c|}{ Table 6: Stability results of optimized formulation at real time $\left(25^{\circ} \mathbf{C} \pm \mathbf{2}^{\circ} \mathbf{C}\right.$ and } \\
$\mathbf{6 0 \%} \% \mathbf{H H})$ storage conditions. \\
\hline \multirow{2}{*}{ Parameter } & \multicolumn{3}{|c|}{ Testing Frequency } \\
\cline { 2 - 4 } & Initial & $\mathbf{3}$ Month & $\mathbf{6}$ Month \\
\hline Description & White to off-white spherical pellets filled in white opaque capsule \\
\hline Moisture content & 2.54 & 2.41 & 2.34 \\
\hline Assay & 100.2 & 99.8 & 99.4 \\
\hline $\mathbf{2}$ & $49.2 \pm 1.3$ & $49.1 \pm 1.7$ & $49.2 \pm 1.9$ \\
\hline $\mathbf{4}$ & $72.8 \pm 0.9$ & $72.4 \pm 1.1$ & $71.8 \pm 1.4$ \\
\hline $\mathbf{6}$ & $82.5 \pm 0.8$ & $83.1 \pm 0.5$ & $83.6 \pm 1.1$ \\
\hline $\mathbf{8}$ & $93.3 \pm 0.9$ & $93.4 \pm 0.7$ & $93.1 \pm 0.4$ \\
\hline
\end{tabular}

\section{CONCLUSION}

Methylphenidate $\mathrm{HCl}$ ER pellets generating a biphasic release profile from single core were successfully fabricated by fluid bed coating technology.Impact of various process variables on drug layering process was assessed by using response surface methodology. This investigation revealed that independent variables had a significant impact on the measured responses. The quantitative effect of these factors at different levels on responses could be predicted by polynomial equations. Linearity observed between the actual and predicted values of the response variables indicated that analytical ability of the selected design. From the obtained results, $40^{\circ} \mathrm{C} \pm 2{ }^{\circ} \mathrm{C}$ as product temperature, $0.8-1.0 \mathrm{~kg} / \mathrm{cm}^{2}$ as atomization air pressure, 45-60 CFM as fluidization air volume and $2-6 \mathrm{~g} / \mathrm{min}$ as spray rate were selected as the operating ranges for robust coating process, desired yield and quality of the product. The optimized batch showed $100.2 \%$ assay and drug release was well within the predetermined specifications (Similarity factor (F2) value - 68). Micrometric properties of these pellets exhibited excellent flow properties, which are crucial to attain the uniformity of dosage units in capsule filling.
The optimized formulation can be used as an alternative to the marketed formulation. Hence, the applicability of response surface methodology to optimize the process variables in the fabrication of Methylphenidate $\mathrm{HCl}$ ER pellets is apt enough.

\section{ACKNOWLEDGEMENT}

Authors are thankful to RA Chem Pharma Ltd, Hyderabad for providing the gift sample of Methylphenidate $\mathrm{HCl}$, polymers and facilities to carry out the research work.

\section{CONFLICT OF INTEREST}

There is no conflict of interest.

\section{ABBREVIATIONS USED}

ER: Extended release; QbD: Quality by design; CCD: Central composite design; RSM: Response surface methodology; ANOVA: Analysis of variance; CMAs: critical material attributes; CQAs: Critical quality attributes; CPPs: Critical process parameters. 


\section{REFFERENCES}

1. Gehbre Sellasie, Pellets: A general overview: Pharmaceutical pelletization technology; $3^{\text {rd }}$ ed, New York: Marcel Dekker Inc, 1989.

2. Hiren P. Patel, J. K. Patel, Ravi R. Patel and Manish P. Patel, Pellets: A general overview, Int. J Pharm World Res, 2010; 2: 1-15.

3. Shajahan A, Anil V. C and Sunil B. J, A flexible technology for modified release drugs: Multiple unit pellets system. J Control Release, 2010; 147: 2-16.

4. Qiu,Y., Chen, Y., Zhang, G.G.Z., Liu.L. And PorterW. R., Developing Solid Oral Dosage Forms: Pharmaceutical Theory and Practice, $1^{\text {st }}$ ed, New York: Academic Press, David Jones, 2009.

5. International Conference on harmonization (ICH). Guidance for industry: Q8 (R2) Pharmaceutical development, ICH harmonized tripartite guideline, 2009

6. Dayal P, Pillay V, Babu RJ and Singh M. Box-Behnken experimental design in the development of a nasal drug delivery system of model drug hydroxyurea: Characterization of viscosity, in vitro drug release, droplet size and dynamic surface tension. AAPS Pharm Sci Tech 2005;6: E573-85.

7. Shetty, V., Wurster Coating- Scale up and Scale out. Pharma Times, 2010, 42(11), 33-37.

8. Krunal M. Upadhyay et al, Formulation and evaluation of oral controlled porosity osmotic pump tablet of Methylphenidate $\mathrm{HCl}$, Pharma Science Monitor, 2013, 4 (3), P: 20-30
9. Sudheer et al, Formulation and in-vitro Characterization of Methyl Phenidate Extended Release Capsules, Sch. Acad. J. Pharm., 2015; 4(1): 10-15

10. Bala Vishnu Priya M, Murthy T. E. G. K and Prameela Rani A, Multi-particulate Drug Delivery Systems of Methylphenidate Hydrochloride: Optimization of Formulation Using Statistical Experimental Design, Asian J Pharm, 2017, 11 (3), 239-249.

11. Lachman L, Liberman HA, Kanig JL. The Theory and practice of Industrial Pharmacy, $3^{\text {rd }}$ ed, India: Varghese Publishing house, Bolton S. 1987;243-89.

12. USP. <616> Bulk density and tapped density. USP30 NF 25 (2007).

13. Methylphenidate Hydrochloride Tablets; U.S. Pharmacopoeia-National Formulary, USP 29 NF 24, United States Pharmacopeial Convention, Inc; 2014, 1406

14. https://www.accessdata.fda.gov/scripts/cder/dissolution/dsp_SearchResults. cfm;(Last accessed on 2017 June 20)

15. Suvakanta D, Padala N M, Lilakanta N and Chowdhury P, Kinetic Modeling on Drug Release from Controlled Drug Delivery Systems, Acta Pol. Pharm., 2010, 67: 217-23.

16. Q1A (R2) Stability Testing of New Drug Substances and Products, International Council for Harmonisation, Revision 2, 2003.

\section{PICTORIAL ABSTRACT}
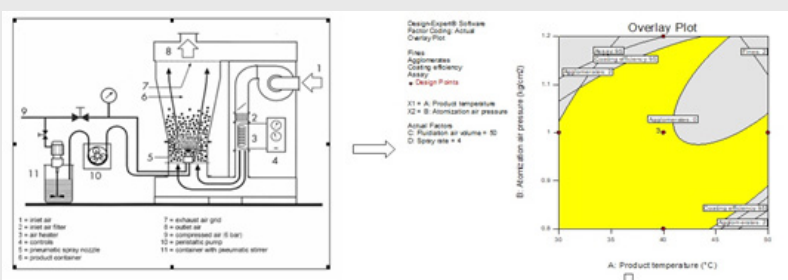

an

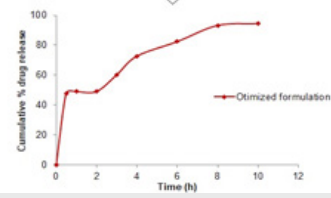

\section{SUMMARY}

- The Methylphenidate $\mathrm{HCl}$ ER pellets were successfully prepared by employing wurster process

- Impact of various process variables (product temperature, atomization air pressure, fluidization air volume, and spray rate) was assessed by using central composite design

- The process parameters, $40^{\circ} \mathrm{C} \pm 2^{\circ} \mathrm{C}$ as product temperature, $0.8-1.0 \mathrm{~kg} / \mathrm{cm} 2$ as atomization air pressure, 45-60 CFM as fluidization air volume and $2-6 \mathrm{~g} / \mathrm{min}$ as spray rate were selected as the operating ranges for robust coating process, desired yield and quality of the product.

\section{About Authors}

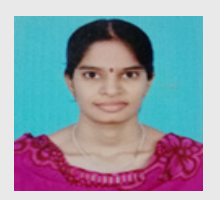

Bala Vishnu Priya Mukkala, M.Pharm, working as a senior research associate in Formulation Research and development, RA Chem Pharma Ltd. She is having 5 years of research experience. Her research interest is in the area of advanced drug delivery systems. Currently perusing part time Ph.D. from JNTU, kakikinada, under the guidance of Dr. T.E.Gopala Krishna Murthy Professor and principal, Bapatla college of pharmacy,Bapatla and Dr. Prameela Rani Avula, Principal and Professor, University College of Pharmaceutical Sciences Acharya Nagarjuna University Nagarjuna Nagar, Guntur on "Design Development and Evaluation of Oral Modified Drug Delivery systems for Selected drugs".

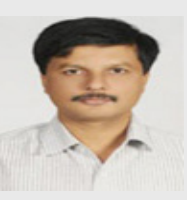

Dr. T.E. Gopala Krishna Murthy, M. Pharm., Ph. D. Principal, Professor, Bapatla College of Pharmacy served as an academic supervisor to more than 60 Master Degree dissertations and 14 Ph.D Degree dissertations for the award of M.Pharm and PhD Degrees. He has published many research articles in reputed national and international Journals. He received fellowship from Association of Pharmacy and Biotechnology, AP Academy of Sciences and is a recipient of meritorious teacher award from JNTUK, Kakinada. He is acting as Editorial Board Member for various journals, authored 4 text books and filed for 10 Patents. He acted as Convener for two AICTE Sponsored National Seminars and two Staff Development Programmes. He was granted generous funds from AICTE under RPS and MODROBS Schemes during his academic service till now. 


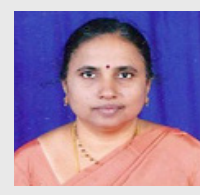

Dr. Prameela Rani Avula, Principal and Professor University College of Pharmaceutical Sciences Acharya Nagarjuna University Nagarjuna Nagar, Guntur. Carried out the research work under the guidance of Prof. K P R Chowdary, AU and was awarded the Ph.D from JNTU, Hyderabad in the year 2005. she is having 26 yrs of teaching includes 21 yrs of Research Experience,Major research projects funded by UGC - 1 (11 Lakhs sanctioned by UGC) AICTE - 1 (15 Lakhs sanctioned by AICTE) She has published many research articles in reputed national and international Journals. She has shared his research experience on the platforms of national and international conferences, workshops, seminars and symposia.

Cite this article: Mukkala BVP, TEGK M, Rani PA. Process Optimization of Methylphenidate Hydrochloride Extended Release Pellets by Obd. Indian J of Pharmaceutical Education and Research. 2017;51(4S):S548-S58. 